\title{
Effect of Soil Preparation Depth on Nutrient Leaching and Nutrient Uptake by Young Vitis vinifera L. cv. Pinot noir
}

\author{
W.J. Conradie ${ }^{1}$, J.L. Van Zyl ${ }^{2}$ and P.A. Myburgh ${ }^{1}$ \\ 1) Nietvoorbij Institute for Viticulture and Oenology, Agricultural Research Council, Private Bag X5026, 7599 Stellenbosch, South Africa \\ 2) Institute for Tropical and Subtropical Crops, Agricultural Research Council, Private Bag X11208, 1200 Nelspruit, South Africa
}

Submitted for publication: October 1996

Accepted for publication: December 1996

Key words: Grapevine, soil preparation, mineralisation, leaching, nutrient demand, soil depth, non-bearing

\begin{abstract}
The effect of soil preparation depth on leaching of $\mathrm{N}, \mathrm{Ca}, \mathrm{Mg}$ and $\mathrm{K}$ was determined for a granitic soil by means of field lysimeters. For this purpose trenches $(22,5 \mathrm{~m} \times 2,7 \mathrm{~m})$ with depths of $400 \mathrm{~mm}(\mathrm{T40}), 800 \mathrm{~mm}$ (T80) and $1200 \mathrm{~mm}$ (T120) were excavated, lined with plastic sheets and fitted with drainage pipes. After refilling the soil in the original sequence each lysimeter was planted with fifteen Pinot noir vines grafted onto 99 Richter, two years after soil preparation. The experimental site was situated on a 15 degree slope and drained naturally. Leachates were collected quantitatively and analysed. Nutrient uptakes of vines were determined up to the end of the third growing season. Soil loosening stimulated the mineralisation of organic material, resulting in leaching of nitrates. Higher amounts were leached from the deeper treatments and losses declined over time. Results indicated that soil-derived $\mathrm{N}$ can supply the $\mathrm{N}$ requirement of grapevines for the first three years after soil preparation. Leaching losses of $\mathrm{Ca}, \mathrm{Mg}$ and $\mathrm{K}$ pointed to a steady state being attained four to five years after soil preparation. Once this state had been attained, annual Ca losses were approximately $200 \mathrm{~kg} . \mathrm{ha}^{-1}$, irrespective of soil preparation depth. Magnesium losses correlated with preparation depth, ranging from $20 \mathrm{~kg} . \mathrm{ha}^{-1}$ for T40 to $70 \mathrm{~kg} . \mathrm{ha}^{-1}$ for T120. Potassium losses rarely exceeded $20 \mathrm{~kg}^{-\mathrm{ha}^{-1}}$, thus not necessitating any major adjustments in fertilisation programmes. Soil preparation depth had a significant effect on the development of the young vines. Full bearing stage was reached at the end of the second season for T120 and the end of the third season for T80 and T40. During the second growing season foliar nitrogen uptake amounted to $12,6 \mathrm{~kg} . \mathrm{ha}^{-1}, 15,2 \mathrm{~kg} \cdot \mathrm{ha}^{-1}$ and $24,5 \mathrm{~kg}^{-1} \mathrm{ha}^{-1}$ for T40, T80 and T120, respectively. In the third season $\mathbf{N}$ uptake on T120 $\left(52,5 \mathrm{~kg}^{-h^{-1}}{ }^{-1}\right)$ was comparable to that of mature vines while T80 $\left(37,2 \mathrm{~kg} . \mathrm{ha}^{-1}\right)$ and T40 $\left(31,5 \mathrm{~kg}^{-1} \mathrm{ha}^{-1}\right)$ required considerably less $\mathrm{N}$. During the non-bearing stage the Ca uptake was comparable to that of $\mathrm{N}$ and $60 \%$ higher than that of $\mathrm{K}$. When the first grapes were harvested (third season), $\mathrm{K}$ uptake surpassed that of Ca for T40 and T80. Magnesium uptake never exceeded $15 \mathrm{~kg} . \mathrm{ha}^{-1}$, irrespective of soil depth.
\end{abstract}

A large percentage of South African vineyards are cultivated on naturally compact soils (Van Huyssteen, 1989). This compaction must be alleviated before vines can be planted, thus necessitating soil loosening. Due to soils being disturbed during soil preparation, structural units are fractured and fresh faces exposed to weathering forces. Rapid initial leaching of basic cations can therefore be expected, before a steady state is attained after several years (Wood \& Pettry, 1989). Leaching of exchangeable bases from soils has been quantified for many areas (Neilsen \& Stevenson, 1983). However, the amount of cations lost during the initial stage after deep soil preparation, and the time needed to attain a steady state, are not known for soils and soil preparation practices in South Africa.

Deep soil preparation implies drastic soil disturbance, and mineralisation of organic $\mathrm{N}$ should be greatly enhanced (Haynes, 1986; Myers, 1988). A major portion of mineralised $\mathrm{N}$ may leach out of the soil profile (Stevenson \& Nielsen, 1990), but soil-derived $N$ could still be sufficiently high to supply the $\mathrm{N}$ requirement of young grapevines. When soils are loosened to depths of more than $800 \mathrm{~mm}$, deeper layers make a substantial contribution to the pool of mineral N (Hadas et al., 1986) and addition of inorganic fertilisers may be unnecessary during the first few years after planting. However, while the nutritional requirements of bearing grapevines have been investigated in several countries, as reviewed by Conradie (1991), little research has been done on young vines. Fertilisation programmes for young vines are therefore not scientifically based.
The first objective of this study was to determine the effect of soil preparation depth on the absolute amounts of $\mathrm{N}, \mathrm{Ca}, \mathrm{Mg}$ and $\mathrm{K}$ which are leached from a vineyard soil during the first three years after planting. Secondly, the uptake of nutrients by young grapevines up to the full-bearing stage, was to be determined.

\section{MATERIALS AND METHODS}

Lysimeters: The study was carried out at Stellenbosch, on a granitic Glenrosa soil (Soil Classification Work Group, 1991) with a slope of $15^{\circ}$. Field lysimeters with depths of $400 \mathrm{~mm}$ (T40), $800 \mathrm{~mm}$ (T80) and $1200 \mathrm{~mm}$ (T120), respectively, were constructed during 1984. Each treatment was replicated five times in a randomised block design For each replicate a trench of 22,5 m x 2,7 m , was dug to the required depths, using an excavator. All plots ran downhill to facilitate drainage of free soil water. Adjacent lysimeters were separated by $300 \mathrm{~mm}$ of undisturbed soil. Upper $(0-600 \mathrm{~mm})$ and lower (deeper than $600 \mathrm{~mm}$ ) layers were kept separate. Lime requirements were determined by Eksteen's method (Eksteen, 1969). Agricultural lime needed to raise the $\mathrm{pH}(\mathrm{KCl})$ to 6,0 amounted to 4,5 and $5,4 \mathrm{~kg} \cdot \mathrm{m}^{-3}$ for the topsoil and subsoil, respectively. Phosphorous content was determined with the Bray No. 2 method. The amount of superphosphate $(10,5 \% \mathrm{P})$ necessary to raise $\mathrm{P}$ content to $25 \mathrm{mg} . \mathrm{kg}^{-1}$ amounted to $221 \mathrm{~g} \cdot \mathrm{m}^{-3}$ and 317 g. $^{-3}$ for upper and lower layers, respectively. Agricultural lime and superphosphate were broadcast over the excavated soil and mixed into the soil by means of the 
excavator. Trenches were lined with $0,5 \mathrm{~mm}$ thick plastic sheets and drainage pipes ( $75 \mathrm{~mm}$ diameter), covered with gravel, laid down the middle of each trench. Pipes passed through watertight seals in the plastic at the lower ends of the lysimeters. All lysimeters could, therefore, drain quantitatively by means of gravitation. Ameliorated soil was replaced in the trenches in the original sequence.

Leachates from the lysimeters were collected in separate $0,8 \mathrm{~m}^{3}$ tanks fitted with siphoning devices and water meters. As soon as a tank was full, it emptied automatically through the siphon and the volume of leachate was recorded. Due to logistical problems the system was not completely functional before the spring of 1986, i.e. two years after soil preparation.

Experimental Vineyard: After construction of the lysimeters the soil was left to stabilise for one season. Experimental vines (Pinot noir/99 Richter) were planted during 1985. However, due to establishment problems (Myburgh, Van Zyl \& Conradie, 1996), vines were replanted in September 1986. Consequently, the third year after soil preparation (1986/87) was regarded as the first growing season. Vines were spaced $1,5 \mathrm{~m}$ apart, resulting in 15 vines per lysimeter. The thirteen middle vines were used as experimental vines. Vines were trained to a lengthened Perold trellis, described by Zeeman (1981). Soil was mulched annually with wheat straw (approximately 7 ton.ha ${ }^{-1}$ ). To prevent mechanical soil compaction, no vehicle traffic was allowed in the vineyard after planting. The few weeds that emerged were controlled chemically.

The first growing season was used to develop the stems of the vines by leading one shoot up to the first cordon wire. Cordon arms were developed partially in the second (1987/88) season (Myburgh et al., 1996). Most bunches were removed and grape yield was insignificant. Cane masses were determined in July. During the third season (1988/89) cordons were developed fully. Yield was limited to approximately 12 bunches per vine. Grapes were harvested at the end of January and cane masses determined in July.

During the first two growing seasons the vines received a spring application of $15 \mathrm{~kg} \mathrm{~N} \cdot \mathrm{ha}^{-1}$ in the form of limestone ammonium nitrate, while no $\mathrm{N}$ was applied during the third (1988/1989) season. Vines were irrigated weekly from the middle of November to the end of March by means of a micro sprinkler system, as described by Myburgh et al. (1996).

Sampling and analyses: The soil was sampled before preparation and again two years later. In the latter case T40 and T80 were sampled to the depth of soil preparation but T120 to $1100 \mathrm{~mm}$ only, in order to prevent damage to the plastic linings of the lysimeters. Analyses for particle size, $\mathrm{pH}(1 \mathrm{M} \mathrm{KCl}), \mathrm{P}$ (Bray No. 2), $\mathrm{K}, \mathrm{Ca}, \mathrm{Mg}$, cation exchange capacity (CEC), $\mathrm{C}$ and total $\mathrm{N}$ were carried out according to standard Nietvoorbij methods. During the third year after soil preparation (vines in their first leaf) the soil was sampled in spring (end of September) and autumn (April). The $\mathrm{NH}_{4}-\mathrm{N}$ and $\mathrm{NO}_{3}-\mathrm{N}$ contents of these samples were determined by means of steam distillation, as described by Bremner (1965).

Leachates from all tanks were sampled once a week, starting in the first growing season (1986/87). After sampling the tanks were emptied and volumes recorded. The $\mathrm{NO}_{3}-\mathrm{N}$ and $\mathrm{NH}_{4}-\mathrm{N}$ concentrations of all samples were determined by steam distillation (Bremner, 1965). Composite samples from individual plots were analysed monthly for $\mathrm{Ca}, \mathrm{Mg}$ and $\mathrm{K}$, using an atomic absorption spectrophotometer.

Calculation of nutrient uptake: Shoots and leaves were not analysed in the first growing season. However, with the plants still being relatively small, nutrient uptake for any specific element was assumed to be less than 10 $\mathrm{kg} . \mathrm{ha}^{-1}$. During the second and third growing seasons, canes were weighed and analysed for $\mathrm{N}, \mathrm{Ca}, \mathrm{Mg}$ and $\mathrm{K}$, according to standard Nietvoorbij procedures. From these values absolute amounts of nutrients present in the canes were calculated. Leaves were not analysed in the second season. In the third season leaves were sampled at the start of leaf-fall and analysed. The number of leaves per plant was counted for three vines from each treatment and average dry mass per leaf determined. These values were used to calculate amounts of nutrients present in the leaves. Distribution of nutrients between canes and leaves (canes:leaves) amounted 1,84 for $\mathrm{N} ; 4,81$ for $\mathrm{Ca} ; 1,19$ for $\mathrm{K}$ and 2,75 for $\mathrm{Mg}$. Previous research (Conradie, 1981; 1991) indicated that this ratio remains fairly constant for spur-pruned grapevines and the above values were also used to calculate amounts of nutrients present in leaves during the second season. During the second growing season no bunches were present. In the third season bunches were weighed but not analysed. Subsequent work (not shown) indicated that the ton of fresh Pinot noir grapes contains $1,39 \mathrm{~kg} \mathrm{~N} ; 0,17$ $\mathrm{kg} \mathrm{Ca} ; 1,98 \mathrm{~kg} \mathrm{~K}$ and $0,09 \mathrm{~kg} \mathrm{Mg}$. Nutrient contents of bunches were estimated from these values.

\section{RESULTS AND DISCUSSION}

Soil analyses: Particle size analysis of the soil fraction $<2 \mathrm{~mm}$, showed that the clay content remained fairly constant down to a depth of $1200 \mathrm{~mm}$ (Myburgh et al., 1996). The $0-300 \mathrm{~mm}$ layer, however, contained nearly three times more grit (fraction $>2 \mathrm{~mm}$ ) than the $900-1200 \mathrm{~mm}$ layer. When the grit fraction was also taken into account (Table 1), the effective clay content of the topsoil (0 -300 $\mathrm{mm}$ ) decreased to $13,3 \%$, in comparison to $25,4 \%$ for the $900-1200 \mathrm{~mm}$ layer. This pointed to a a high percentage of macropores in the topsoil, thereby enhancing water infiltration and curtailing runoff.

Chemical analyses of the soil, before preparation, indicated low $\mathrm{pH}$ values and $\mathrm{P}$ content (Table 2). This is typical for granitic soils from the Western Cape, necessitating addition of lime and phosphate. The $\mathrm{K}$ content of the soil was sufficient to supply the need of grapevines for at least 
TABLE 1

Particle size distribution (\%) for granitic Glenrosa soil near Stellenbosch.

\begin{tabular}{|c|c|c|c|c|}
\hline $\begin{array}{c}\text { Soil Depth } \\
(\mathrm{mm})\end{array}$ & $\begin{array}{c}\text { Clay }^{(1)} \\
(<0,002 \mathrm{~mm})\end{array}$ & $\begin{array}{c}\text { Silt } \\
(0,002-0,05 \mathrm{~mm})\end{array}$ & $\begin{array}{c}\text { Sand } \\
(0,05-2,0 \mathrm{~mm})\end{array}$ & $\begin{array}{c}\text { Grit } \\
(2,0-20,0 \mathrm{~mm})\end{array}$ \\
\hline $0-300$ & 13,3 & 13,6 & 26,8 & 47,1 \\
\hline $300-600$ & 18,3 & 19,5 & 35,0 & 27,3 \\
\hline $600-900$ & 19,4 & 18,5 & 39,9 & 24,0 \\
\hline $900-1200$ & 25,4 & 20,1 & 38,7 & 16,8 \\
\hline
\end{tabular}

(1) "Effective" concentrations. Grit, sieved from soil before clay, silt and sand were determined in the laboratory, was taken into account in order to calculate "effective" concentrations.

TABLE 2

Chemical analysis of a granitic Glenrosa soil near Stellenbosch before soil preparation.

\begin{tabular}{|c|c|c|c|c|c|}
\hline $\begin{array}{c}\text { Depth } \\
(\mathrm{mm})\end{array}$ & $\mathrm{pH}(\mathrm{KCI})$ & $\begin{array}{c}\mathrm{p}^{(1)} \\
\left(\mathrm{mg} \cdot \mathrm{kg}^{-1}\right)\end{array}$ & $\begin{array}{c}\mathrm{K}^{(1)} \\
\left(\mathrm{mg} \cdot \mathrm{kg}^{-1}\right)\end{array}$ & $\begin{array}{c}\mathrm{Ca}^{(2)} \\
\left(\mathrm{cmol}_{\mathrm{c}} \mathrm{kg}^{-1}\right)\end{array}$ & $\begin{array}{c}\mathrm{Mg}^{(2)} \\
\left(\mathrm{cmol}_{\mathrm{c}} \mathrm{kg}^{-1}\right)\end{array}$ \\
\hline $0-300$ & 4,25 & 20 & 112 & 1,35 & 0,50 \\
\hline $300-600$ & 4,20 & 5 & 67 & 1,19 & 0,48 \\
\hline $600-900$ & 4,15 & 2 & 60 & 0,51 & 0,75 \\
\hline $900-1200$ & 4,05 & 2 & 70 & 0,40 & 1,00 \\
\hline
\end{tabular}

(1) Extracted with Bray -2 .

(2) Extracted with $1 \mathrm{M} \mathrm{NH}_{4} \mathrm{OAc}$.

10 years (Conradie \& Saayman, 1989). In the clayey subsoil $(600-1200 \mathrm{~mm})$ an accumulation of $\mathrm{Mg}$ occurred, at the expense of $\mathrm{Ca}$. This is commonly an indication of soil compaction and/or a strong structure.

Two years after liming, soil $\mathrm{pH}$ was within 0,25 units of the goal $(6,0)$ over all depths (Table 3 ). At these $\mathrm{pH}$ values problems with soil acidity are effectively eliminated (Conradie, 1983). The amount of $P$ added should have raised the $\mathrm{P}$ content to $25 \mathrm{mg} \cdot \mathrm{kg}^{-1}$ over the whole profile. Lower values in the subsoil $(600-1100 \mathrm{~mm})$ indicated fixing of applied $\mathrm{P}$, which was apparently more severe in the layers with higher clay contents (Table 1). However, in view of relatively high values in the topsoil $(0-600 \mathrm{~mm})$, grapevines should be adequately supplied with P (Conradie \& Saayman, 1989). Potassium content was nearly identical to the value obtained before soil preparation, while increased $\mathrm{Ca}$ contents reflected the addition of calcitic lime.

The $\mathrm{C}$ content of the soil was fairly constant down to $900 \mathrm{~mm}$, while a lower value was found in the $900-1100 \mathrm{~mm}$ layer. The $\mathrm{C} / \mathrm{N}$ ratio of 10,7 in the topsoil $(0-150 \mathrm{~mm})$ is normal for well-aerated vineyard soils, indicating a satisfactory rate of mineralisation (Champagnol, 1980). In the $150-1100 \mathrm{~mm}$ layer $\mathrm{C} / \mathrm{N}$ ratio was higher, pointing to a lower mineralisation rate.

In the spring of 1986/1987 (third year after soil preparation) $\mathrm{NO}_{3}-\mathrm{N}$ tended to be highest in the $900-1100 \mathrm{~mm}$ layer (Table 4). A higher clay content in this layer (Table 1) may have led to a higher proportion of micropores. Nitrates, present within the micropores of aggregates, could have been bypassed by the bulk of flowing water (Haynes, 1986; White, 1988), thus being protected against leaching. High $\mathrm{NO}_{3}-\mathrm{N}$ contents in the autumn samples indicated a high rate of mineralisation during summer, when vines were irrigated weekly. The $\mathrm{NH}_{4}-\mathrm{N}$ content of the samples never exceeded 2,54 mg. $\mathrm{kg}^{-1}$, thus making only a minor contribution to the pool of mineral $\mathrm{N}$, which is in agreement with results obtained by Raath \& Saayman (1995).

\section{Drainage}

Annual pattern: The rainy season at Stellenbosch nor- 


\begin{tabular}{|c|c|c|c|c|}
\hline z & $\frac{\pi}{\stackrel{0}{0}}$ & $\begin{array}{c}0 \\
\dot{\sigma} \\
\end{array}$ & $\begin{array}{l}\overrightarrow{0} \\
\stackrel{n}{ \pm}\end{array}$ & $\begin{array}{l}\stackrel{0}{\infty} \\
\text { @) }\end{array}$ \\
\hline 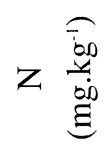 & $\underset{D}{\infty}$ & $\begin{array}{l}0 \\
\stackrel{7}{\gamma} \\
\gamma\end{array}$ & $\begin{array}{l}0 \\
\text { Dे } \\
\text { r }\end{array}$ & $\begin{array}{l}0 \\
\hat{a} \\
\text { ते }\end{array}$ \\
\hline $0 \widehat{e}$ & $\begin{array}{l}\tilde{\sigma} \\
\tilde{U} \\
\tilde{O}\end{array}$ & $\frac{\pi}{2}$ & $\begin{array}{l}\pi \\
i n \\
0\end{array}$ & $\frac{\sigma}{n}$ \\
\hline
\end{tabular}

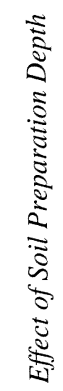

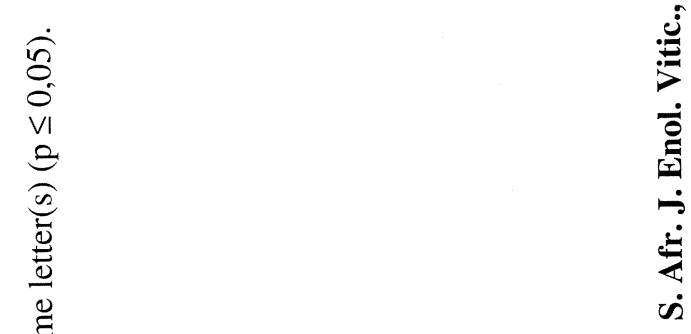


TABLE 4

Inorganic $\mathrm{N}$ concentrations in a granitic Glenrosa soil near Stellenbosch during the third year after soil preparation $\left(\mathrm{mg} \mathrm{N}^{\mathrm{kg}} \mathrm{kg}^{-1}\right)\left({ }^{-1}\right)$.

\begin{tabular}{|c|c|c|c|c|c|c|}
\hline \multirow{2}{*}{$\begin{array}{l}\text { Soil Depth } \\
\quad(\mathrm{mm})\end{array}$} & \multicolumn{3}{|c|}{ Spring } & \multicolumn{3}{|c|}{ Autumn } \\
\hline & $\begin{array}{c}\mathrm{NO}_{3-\mathrm{N}} \\
\left(\mathrm{mg} \cdot \mathrm{kg}^{-1}\right)\end{array}$ & $\begin{array}{c}\mathrm{NH}_{4 \cdot-\mathrm{N}} \\
\left(\mathrm{mg} \cdot \mathrm{kg}^{-1}\right)\end{array}$ & $\begin{array}{c}\text { Total inorganic } \mathrm{N}^{(2)} \\
\left(\mathrm{kg}^{2} \cdot \mathrm{ha}^{-1}\right)\end{array}$ & $\begin{array}{c}\mathrm{NO}_{3}-\mathrm{N} \\
\left(\mathrm{mg} \cdot \mathrm{kg}^{-1}\right)\end{array}$ & $\begin{array}{l}\mathrm{NH}_{4}-\mathrm{N} \\
\left(\mathrm{mg} \cdot \mathrm{kg}^{-1}\right)\end{array}$ & $\begin{array}{c}\text { Total inorganic } \mathrm{N}^{(2)} \\
\left(\mathrm{kg} \cdot \mathrm{ha}^{-1}\right)\end{array}$ \\
\hline $0-150$ & $3,77 \pm 0,65$ & $2,54 \pm 0,48$ & 14,2 & $23,4 \pm 4,0$ & $1,65 \pm 0,38$ & 56,4 \\
\hline $150-300$ & $3,43 \pm 0,53$ & $1,85 \pm 0,41$ & 11,9 & $15,4 \pm 2,6$ & $1,40 \pm 0,48$ & 37,8 \\
\hline $300-600$ & $2,69 \pm 0,32$ & $1,07 \pm 0,25$ & 16,9 & $8,6 \pm 1,8$ & $1,27 \pm 0,31$ & 44,4 \\
\hline $600-9000$ & $4,14 \pm 0,56$ & $0,82 \pm 0,28$ & 22,3 & $11,6 \pm 2,8$ & $1,27 \pm 0,34$ & 57,9 \\
\hline $900-1100$ & $5,16 \pm 0,71$ & $1,38 \pm 0,37$ & 19,6 & $11,0 \pm 3,5$ & $1,84 \pm 0,58$ & 38,5 \\
\hline
\end{tabular}

(1) Average values for matching depths (T40, T80 and T120.

(2) Total inorganic $\mathrm{N}$ was calculated from concentration figures, using a bulk density of $1500 \mathrm{~kg} \cdot \mathrm{m}^{-3}$.

mally lasts from April to September, with $76 \%$ of the annual precipitation (on average $713 \mathrm{~mm}$ ) occurring during this period. Drainage correlated with this rainfall pattern. Lysimeters normally drained freely during winter, stopped during October and restarted when irrigation was commenced in November. From July 1987 to June 1988 (fourth season after soil preparation), drainage volumes varied from $440 \mathrm{~mm}$ for T40 to $416 \mathrm{~mm}$ for T120 (not shown), with most of this originating from rainfall. Total irrigation of $439 \mathrm{~mm}$, applied in 21 weekly increments from November to March (Myburgh et al., 1996), induced drainage of $24 \mathrm{~mm}$ and $36 \mathrm{~mm}$ for T120 and T80, respectively. Drainage following each irrigation thus varied between $1 \mathrm{~mm}$ and $2 \mathrm{~mm}$. Irrigation caused higher drainage of $66 \mathrm{~mm}$ for T40, probably due to a lower water-holding capacity for the shallower soil (Myburgh et al., 1996). However, even for this treatment, irrigation still accounted for only $15 \%$ of the annual drainage, substantiating the fact that judiciously applied irrigation causes insignificant leaching, in comparison to that induced by rainfall (White, 1988).
Nutrient concentrations: From 1986 to 1989 nitrate levels in leachates decreased steadily, indicating that a steady state was being attained. The seasonal trend for $1987 / 88$ is shown in Figure 1. In July leachate from T120 had the highest concentration, which is in agreement with higher $\mathrm{NO}_{3}-\mathrm{N}$ levels in the $900-1100 \mathrm{~mm}$ soil layer in spring (Table 4). After the first irrigation on 11 November, leachate from the shallowest treatment (T40) showed high $\mathrm{NO}_{3}-\mathrm{N}$, indicating that rewetting of the soil caused active mineralisation of organic N (Agarwal, Singh \& Kanehiro, 1971). The deeper, more clayey subsoil acted as a buffer against leaching and for T120 nitrate levels only started to increase in January. The first substantial autumn rains in April were also followed by increased leaching of nitrate

At the start of the investigation (1986), Ca level in leachates amounted $95 \mathrm{mg} . \iota^{-1}$ for T120 against only 70 mg. $\iota^{-1}$ for T40. A steady decline was observed up to 1990 (sixth year after soil preparation), at which point the $\mathrm{Ca}$ level stabilised at approximately $40 \mathrm{mg} . \ell^{-1}$, irrespective of soil preparation depth (not shown). For $\mathrm{Mg}$, a declining

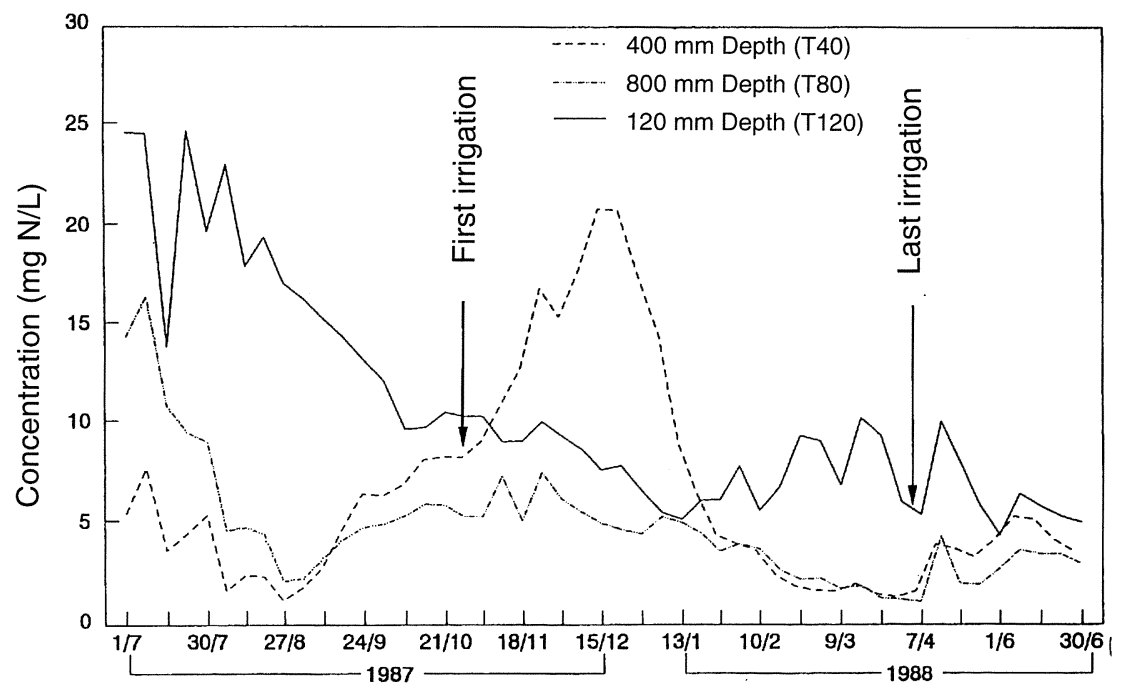

FIGURE 1

Annual variation in nitrate- $\mathrm{N}$ concentration of leachates from field lysimeters with varying depths on a granitic soil. 
TABLE 5

Effect of soil preparation depth on leaching losses of $\mathrm{N}, \mathrm{Ca}, \mathrm{Mg}$ and $\mathrm{K}$ from a granatic Glenrosa soil planted to Pinot noir grapevines, Stellenbosch.

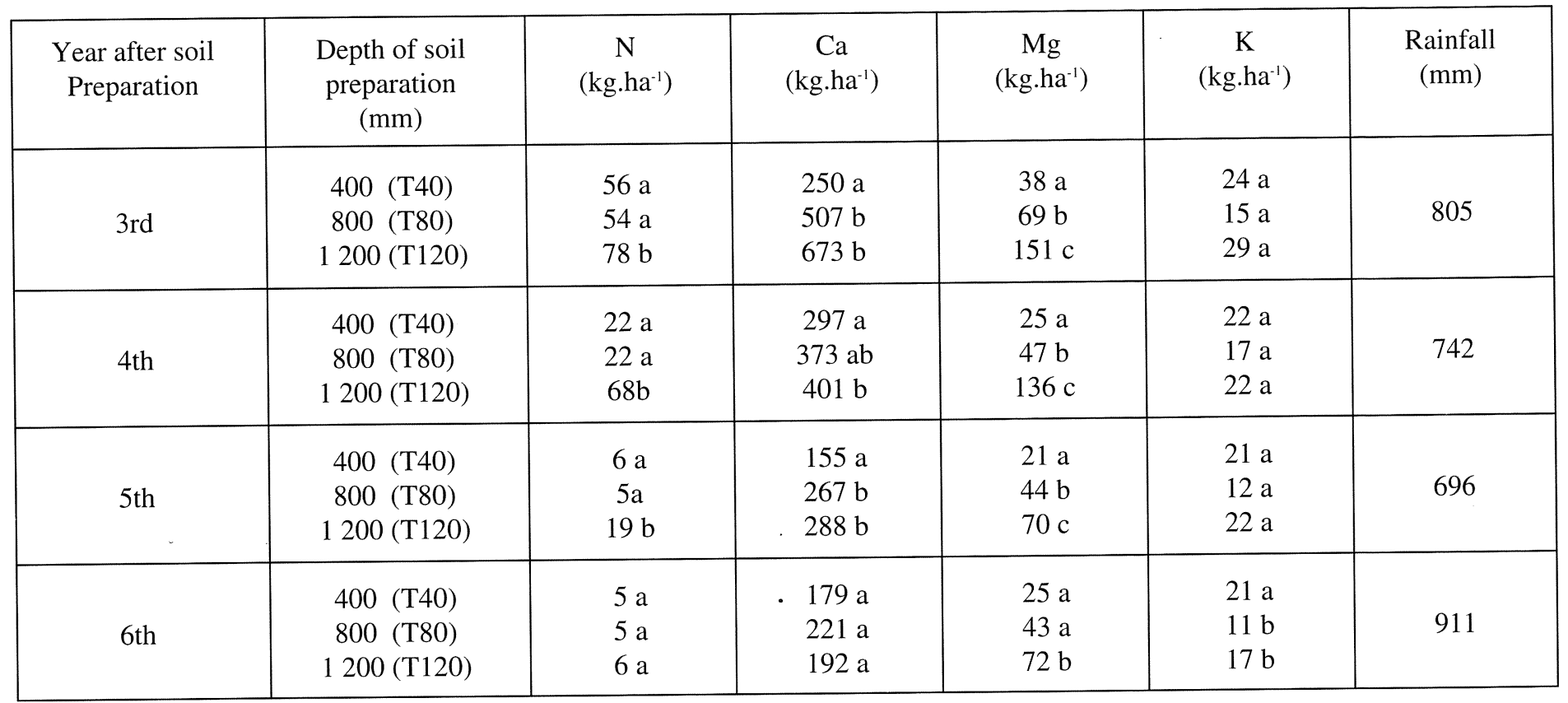

Groups of means for a specific season do not differ significantly if followed by the same letter(s) $(\mathrm{p} \leq 0,05)$.

trend was observed up to a fifth season after soil preparation (1989). At this point the $\mathrm{Mg}$ level in leachates from T120 was approximately $16 \mathrm{mg} . \ell^{-1}$, in comparison to 10 mg. $\ell^{-1}$ for T 80 and $5 \mathrm{mg} . \iota^{-1}$ for T40 (not shown). In contrast to $\mathrm{Ca}$, leaching of $\mathrm{Mg}$ was clearly affected by soil preparation depth. The $\mathrm{K}$ level in leachates remained relatively constant at $3-4 \mathrm{mg} \cdot \mathrm{6}^{-1}$, irrespective of soil preparation depth.

\section{Annual leaching losses}

Nitrogen: During the third year after soil preparation, $\mathrm{N}$ losses exceeded $50 \mathrm{~kg} \cdot \mathrm{ha}^{-1}$ for all treatments (Table 5). Only $15 \mathrm{~kg} \cdot \mathrm{ha}^{-1}$ was applied as fertiliser, indicating that most of the leached $\mathrm{N}$ must have been soil derived. Mineralisation of organic $\mathrm{N}$ was obviously still stimulated on account of the soil having been disturbed (Haynes, 1986; Myers, 1988), even though this had been done three years earlier.

During the fourth year after soil preparation (2nd season), $\mathrm{N}$ losses from T40 and T80 amounted to $22 \mathrm{~kg} \cdot \mathrm{ha}^{-1}$. With only $15 \mathrm{~kg} \mathrm{~N} \mathrm{ha}^{-1}$ having been applied as fertiliser, some soil-derived $\mathrm{N}$ was still being leached. However, in comparison to the previous year, both these treatments showed reduced losses of $\mathrm{N}$, indicating that mineralisation of $\mathrm{N}$ proceeded at a slower rate. This is in agreement with the results of Müller (1993), who found significantly higher leaching during the first three years after soil is loosened. The $1200 \mathrm{~mm}$ treatment showed a $\mathrm{N}$ loss of nearly 70 $\mathrm{kg} \cdot \mathrm{ha}^{-1}$, illustrating the $\mathrm{N}$ supplying capacity of deeper soil layers (Hadas et al., 1986).
Losses from T40 and T80 were down to approximately $5 \mathrm{~kg} \cdot \mathrm{ha}^{-1}$ during the fifth year after soil preparation (3rd season), indicating that a steady state for $\mathrm{N}$ mineralisation/immobilisation had been attained. This state can be compared to the situation in undisturbed deciduous forests, where annual $\mathrm{N}$ losses can range from insignificant (White, 1988) to 3 - 4 kg.ha ${ }^{-1}$ (Haynes, 1986). In such cases the amount of $\mathrm{N}$ lost through leaching may be less than the input from the rainfall. During this year $\mathrm{N}$ loss showed a significant reduction of nearly $50 \mathrm{~kg}, \mathrm{ha}^{-1}$ for $\mathrm{T} 120$, in comparison to the previous year (Table 5). This reduction can be partly ascribed to the fact that no fertiliser $\mathrm{N}$ was added and that the larger vines required more N. During the next year (4th growing season), when the vines were in full production, $\mathrm{N}$ loss from $\mathrm{T} 120$ was down to $6 \mathrm{~kg} \cdot \mathrm{ha}^{-1}$. Thus, this treatment took one year longer to attain a steady state.

Calcium: Leaching loss for T120 was more than 600 $\mathrm{kg} \cdot \mathrm{ha}^{-1}$ during the third year after soil preparation, against only $250 \mathrm{~kg} \cdot \mathrm{ha}^{-1}$ for T40 (Table 5). These amounts were correlated to soil depth and a substantial amount of $\mathrm{Ca}$ must have originated from the agricultural lime added during soil preparation. In general, $\mathrm{Ca}$ losses declined up to the end of the fifth year after soil preparation. During the sixth year after soil preparation Ca losses amounted to approximately $200 \mathrm{~kg} \cdot \mathrm{ha}^{-1}$ for all treatments (Table 5). From this point onwards $\mathrm{Ca}$ losses remained relatively constant (not shown), indicating that a steady state was attained five to six years after soil preparation. Once this state had been attained soil preparation depth did not appear to be of great importance. The annual loss of $150-$ $200 \mathrm{~kg} \cdot \mathrm{ha}^{-1}$ was in agreement with results from the literature (Bolton, Aylesworth \& Hore, 1970; Walter \& Resch 


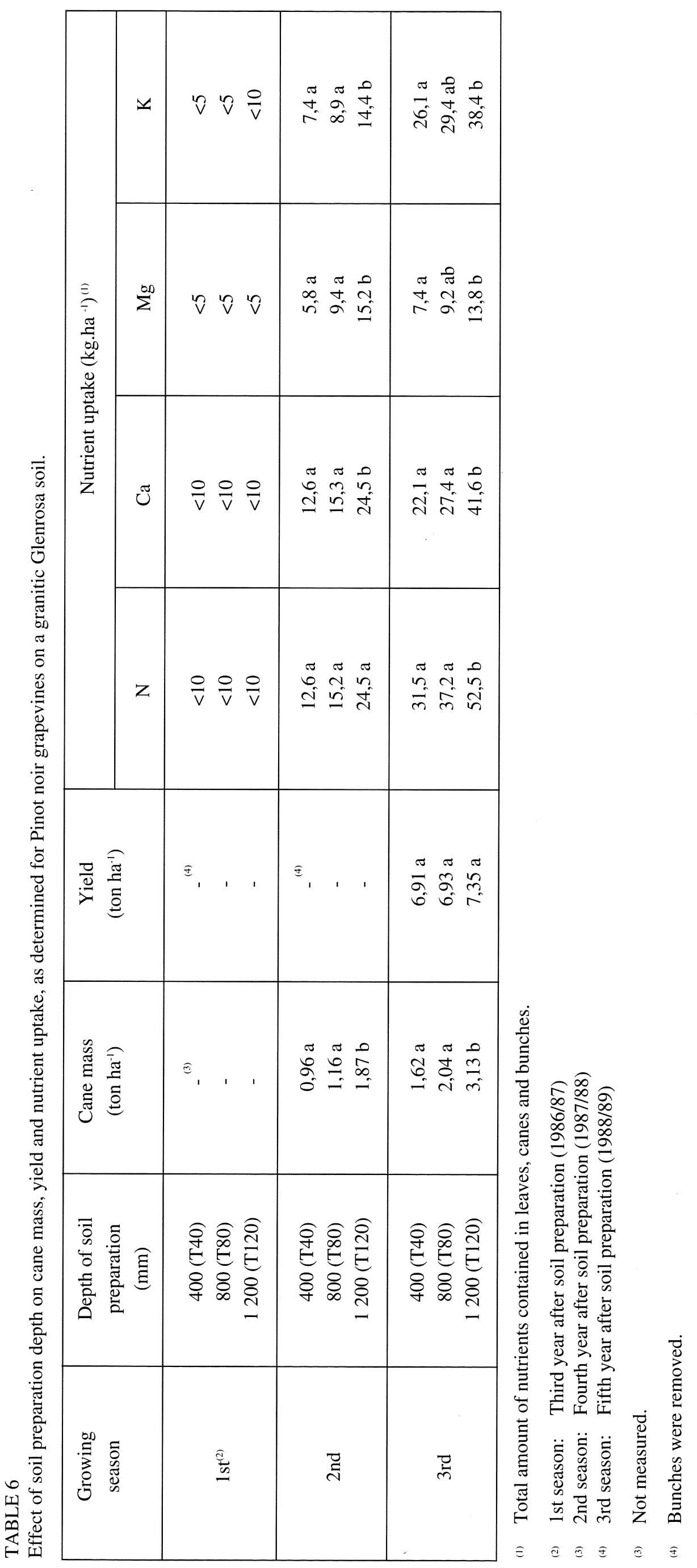


1981). However, in some instances (Jürgens-Gschwind \& Jung, 1979; Neilsen \& Stevenson, 1983) higher amounts of $\mathrm{Ca}$ were lost, probably on account of different soil types and different management practices.

Magnesium: Losses of $\mathrm{Mg}$ indicated that $\mathrm{T} 40$ and $\mathrm{T} 80$ attained a steady state during the fourth year after soil preparation, with annual losses of 25 and $47 \mathrm{~kg} \cdot \mathrm{ha}^{-1}$, respectively (Table 5). The $1200 \mathrm{~mm}$ treatment attained a steady value of approximately $70 \mathrm{~kg}$.ha ${ }^{-1}$ during the fifth year. In the case of $\mathrm{Mg}$, therefore, leaching losses appeared to be correlated to depth of soil preparation. However, the fact that the deeper treatments lost more Mg may also have been caused by high $\mathrm{Mg}$ contents in the deeper soil layers (Table 3).

Potassium: The annual $\mathrm{K}$ loss was fairly constant over the investigation period, averaging $20 \mathrm{~kg} \cdot \mathrm{ha}^{-1}$, irrespective of soil preparation depth (Table 5). Similar amounts were lost in other field trials (Bertsch \& Thomas, 1985). The ratio for $\mathrm{Ca}: \mathrm{Mg}: \mathrm{K}$ losses was comparable to the value of $8: 3: 1$, found in an orchard trial in Canada (Nielsen \& Stevenson, 1983). This pattern may eventually lead to enrichment of soil with $\mathrm{K}$, relative to $\mathrm{Mg}$ and $\mathrm{Ca}$. Potassium fertilisation could accelerate this trend.

\section{Nutrient uptake of young grapevines}

Nitrogen: The first growing season was used to develop the trunks of the vines. Cane and leaf masses were not determined and their nitrogen uptake was assumed to be not more than $10 \mathrm{~kg} \cdot \mathrm{ha}^{-1}$. This amount could easily have been supplied by the soil without any additional fertilisation.

During the second growing season (four years after soil preparation) the cordons of the vines were developed and most bunches were removed. Vines from T120 showed nearly twice as much shoot growth as those from T40, consequently also utilising twice as much $\mathrm{N}$ (Table 6). Soilderived N (Table 4) was clearly sufficient to supply the needs of non-bearing, two-year-old grapevines for all three treatments. However, if vines are planted immediately after soil preparation, in contrast to two years later as was the case in the current investigation, $\mathrm{N}$ uptake during the fourth growing season may well have exceeded $50 \mathrm{~kg} \cdot \mathrm{ha}^{-1}$ (Conradie, 1981), thus being higher than the supplying capacity of the shallower treatments (Table 4).

According to previous results seasonal vegetative growth will demand $1,77 \mathrm{~kg} \mathrm{~N}$ for the production of one ton of grapes (Conradie, 1981). The amount of $\mathrm{N}$ accumulated in leaves and shoots during the second season by T120 vines was therefore comparable to that of mature vineyards yielding 13,8 ton.ha ${ }^{-1}$. This figure would be a realistic target for Pinot noir under the conditions of this experiment, indicating that root systems were fully developed and that vines were ready for full production. The $\mathrm{N}$ uptakes of T40 and T80 were lower than that expected for full-bearing vineyards, confirming that grapevines can go into full production one year earlier if soils are adequately loosened before planting (Myburgh et al., 1996).

The cordons of the vines were fully developed during the third growing season (five years after soil preparation), when the first harvest was obtained (Table 6). However, due to all vines being suckered to 12 bunches per vine, all treatments yielded approximately 7 ton.ha ${ }^{-1}$. Vines on T120 plots showed excessive vegetative growth (Myburgh et al., 1996) and an $\mathrm{N}$ uptake of $52,5 \mathrm{~kg}^{-} \mathrm{ha}^{-1}$ suggested that a larger crop could have been ripened. In California the $\mathrm{N}$ requirement (leaves, shoots and fruit) of 3-year old Thompson Seedless yielding between 24,6 ton.ha ${ }^{-1}$ and 29,1 ton.ha' ${ }^{-1}$, ranged from $59,8 \mathrm{~kg} \cdot \mathrm{ha}^{-1}$ to $65,4 \mathrm{~kg} \cdot \mathrm{ha}^{-1}$ (Araujo, Williams \& Matthews, 1995). Nitrogen uptake of T40 and T80 (31,5 kg.ha ${ }^{-1}$ and 37,2 kg.ha-1) was lower than that of T120, indicating a more acceptable balance between growth and yield.

Calcium: During the first growing season the amount of Ca utilised by foliage was estimated at less than $10 \mathrm{~kg} \cdot \mathrm{ha}^{-1}$ (Table 6). In the second season uptake reflected differences in cane mass. Due to vines not yet being in the full-bearing stage, and to vegetative growth containing similar amounts of $\mathrm{N}$ and $\mathrm{Ca}$, Ca uptake approached that of $\mathrm{N}$ (Table 6). Foliar uptake of $\mathrm{Ca}$ by vines on T120 plots was comparable to that of mature vineyards yielding 14 ton.ha ${ }^{-1}$ (Conradie, 1981), indicating as in the case of $N$, that vines were ready for full production at the end of the second growing season. This state was not attained before the end of the third season for the T40 and T80 treatments. During this (third) season the high Ca uptake by T120 vines $\left(41,6 \mathrm{~kg} \cdot \mathrm{ha}^{-1}\right)$ pointed to luxurious growth conditions.

Magnesium: The pattern for $\mathrm{Mg}$ uptake corresponded to that of $\mathrm{Ca}$ but demand was approximately three times lower (Table 6). In view of these low quantities and the relatively high $\mathrm{Mg}$ content of this soil (Table 3), adequate Mg should be available for several seasons.

Potassium: During the second growing season K uptake was approximately $60 \%$ of that found for $\mathrm{Ca}$. In the third season, when the first grapes were harvested, this trend was reversed for the T40 and T80 treatments. This was due to the $\mathrm{K}$ content of grapes $\left(1,98 \mathrm{~kg} \cdot \mathrm{ton}^{-1}\right)$ being much higher than their Ca content $\left(0,17 \mathrm{~kg} \cdot\right.$ ton $\left.^{-1}\right)$. For T120, where excessive vegetative growth occurred (Myburgh et al., 1996), Ca uptake still exceeded K uptake.

Leaf analyses: Leaf blades from the T40 treatment, sampled at fruit-set in the fourth growing season (1989/90), contained $2,05 \% \mathrm{~N} ; 0,32 \% \mathrm{P} ; 1,45 \% \mathrm{~K} ; 2,05 \% \mathrm{Ca}$ and $0,22 \% \mathrm{Mg}$. This indicated a satisfactory nutritional status for all elements, while similar values were obtained for the T80 and T120 treatments (not shown). Results for peaches (Ran et al., 1994) and previous work on grapevines (Araujo et al., 1995) showed that the $\mathrm{N}$ concentration in leaf blades is not affected by different root volumes. For 
peaches (Ran et al., 1994) it has been suggested that trees with restricted root systems absorb less $\mathrm{N}$ per unit time than trees with larger root systems. This leads to trees with small root volumes producing less dry matter than trees with unrestricted root volumes. In the current study, reduced growth of vines on the shallower treatments can be ascribed to the detrimental effect of a restricted soil volume and it is arguable whether growth will be enhanced by means of additional fertilisation.

\section{CONCLUSIONS}

Field lysimeters, as constructed for this investigation, were relatively inexpensive to operate and leaching losses could be measured quantitatively. The same infrastructure can be used to quantify nutrient balance sheets for fullbearing grapevines.

For this granitic soil, typical of the Western Cape, soil preparation enhanced mineralisation of organic material. Nitrogen leaching losses were not quantified during the first two years after soil preparation, but values obtained during the third season suggested that the annual supply of mineral $\mathrm{N}$ may well have exceeded $100 \mathrm{~kg} \cdot \mathrm{ha}^{-1}$ over the first two years. When this type of soil is loosened to a depth of at least $800 \mathrm{~mm}$, soil-derived $\mathrm{N}$ should satisfy the requirement of grapevines for a minimum of three years. No nitrogen should be applied during the first four years when loosened to greater depths. However, on sandy soils with less organic material and higher leaching rates, nitrogen fertilisation will have to commence sooner.

Annual leaching losses of potassium amounted to 20 $\mathrm{kg} \cdot \mathrm{ha}^{-1}$, while full-bearing grapevines require approximately $40 \mathrm{~kg} \cdot \mathrm{ha}^{-1}$. Experience has shown that the more clayey soils of the Western Cape contain a large reservoir of $\mathrm{K}$, resulting in $\mathrm{K}$ contents of wines being too high. It should, therefore, not be necessary to adjust existing fertilisation programmes in order to compensate for the relatively small leaching loss. For non-bearing grapevines, where annual $\mathrm{K}$ demand will rarely exceed $15 \mathrm{~kg} \cdot \mathrm{ha}^{-1}$, downward adjustment of programmes followed for bearing vineyards will be necessary.

Annual Ca leaching losses exceeded $200 \mathrm{~kg} \cdot \mathrm{ha}^{-1}$. In order to compensate for this, and to prevent soil acidification, at least $500 \mathrm{~kg} \cdot \mathrm{ha}^{-1}$ agricultural lime is required per year. For non-bearing grapevines, $\mathrm{Ca}$ could be the nutrient for which there will be the largest demand. On acidic soils in the Western Cape, where low Ca contents are common, this element should therefore receive more attention in fertilisation programmes for young vines. This will be especially important on shallow soils with low $\mathrm{Ca}$ reserves. Furthermore, in the case of rootstock plantations, where no grapes are produced and a large amount of vegetative growth occurs, annual Ca demand may exceed 300 kg.ha-1 (leaching plus plant uptake). Incorporation of adequate amounts of calcitic lime during soil preparation should receive high priority where plantations are cultivated on soils with low $\mathrm{Ca}$ contents.
Magnesium is known to be a mobile element and appreciable amounts may be leached. However, the $\mathrm{Mg}$ demand of bearing grapevines will rarely exceed $15 \mathrm{~kg} \cdot \mathrm{ha}^{-1}$ and one ton of dolomitic limestone, incorporated during soil preparation, should supply $\mathrm{Mg}$ demand for at least five years.

\section{LITERATURE CITED}

AGARWAL, A.S., SINGH, B.R. \& KANEHIRO, Y., 1971. Soil nitrogen and carbon mineralisation as affected by single drying-re-wetting cycles. Soil Sci. Soc. Am. Proc. 35, 96-100.

ARAUJO, F., WILLIAMS, L.E. \& MATTHEWS, M.A., 1995. A comparative study of young 'Thompson Seedless' grapevines (Vitis vinifera L.) under drip and furrow irrigation. II. Growth, water use efficiency and nitrogen partitioning. Scientia Hortic. 60, 251 - 265.

BERTSCH, P.M. \& THOMAS, G.W., 1985. Potassium status of temperate region soils In: MUNSON, R.D. (ed.) Potasium in agriculture. American Society of Agronomy, Madison, Wisconsin, U.S.A. pp. 131 - 162.

BOLTON, E.F., AYLESWORTH, J.W. \& HORE, F.R., 1970. Nutrient losses through tile drains under three cropping systems and two fertility levels on a Brookston day soil. Can. J. Soil Sci. 50, 275 - 279.

BREMNER, J.M., 1965. Inorganic forms of nitrogen. In: BLACK, C.A. (ed.). Methods of Soil Analysis, Part 2. American Society of Agronomy, Madison, Wisconsin, U.S.A. pp. 1179 - 1237.

CHAMPAGNOL, F., 1980. La matiére organique des sols de vigne du Midi de la France. Progrés agric. Vitic. 97, 161 - 173.

CONRADIE, W.J., 1981. Nutrient consumption by Chenin blanc grown in sand culture and seasonal changes in the chemical composition of leaf blades and petioles. S. Afr. J. Enol. Vitic. 2, $15-18$

CONRADIE, W.J., 1983. Liming and choice of rootstocks as cultural techniques for vines in acid soils. S. Afr. J. Enol. Vitic. 4, 39 - 44.

CONRADIE, W.J., 1991. Translocation and storage of nitrogen by grapevines as affected by time of application. In: RANTZ, J.M. (ed.) Proc, Int. Symp. Nitrogen in Grapes and Wine, Seattle, Washington, U.S.A., 18 - 19 June 1991. pp. $32-42$.

CONRADIE, W.J. \& SAAYMAN, D., 1988. Effects of long-term nitrogen, phosphorous, and potassium fertilisation on Chenin blanc vines. I. Nutrient demand and vine performance. Am. J. Enol. Vitic. 40, 85 - 90.

EKSTEEN, L.L. 1969. The determination of the lime requirement of soils for various crops in the Winter Rainfall Region. Fert. Soc. S. Afr. 2, 13 - 14.

HAdAs, A., FEIGENBAUM, S., FEIGEN, A. \& PORTNOY, R., 1986. Nitrogen mineralisationin profiles of differently managed soil types. Soil Sci. Am. J. 50, 314 - 319.

HAYNES, R.J., 1986. Mineral nitrogen in the plant soil system. Academic Press Inc., Orlando, Florida, U.S.A. 483 pp.

JÜRGENS-GSCHWIND, S. \& JUNG, J., 1979. Results of lysimeter trials at the Limburgerhoff facility, 1927 - 1977: the most important findings from 50 years of experiments. Soil Sci. 127, 146 - 160.

MÜLLER, K., 1993. Der Mineralisation des organisch gebundenen Stickstoff in Weinbergsböden. Teil II. Sickerwasseranfall, Nitratkonzentration und Nitratfracht. Vitis 32, 23 - 34

MYBURGH, P.A., VAN ZYL, J.L. \& CONRADIE, W.J., 1996. Effect of soil depth on growth and water consumption of young Vitis vinifera L. $\mathrm{cV}_{\text {. Pinot }}$ noir. S. Afr. J. Enol. Vitic. 17, 53 - 62.

MYERS, R.J.K., 1988. Nitrogen management of upland crops: from cereals to food legumes to sugarcane. In: WILSON, J.R. (ed.) Advances in nitrogen cycling in Agricultural Ecosystems. CAB International, Wallingford, U.K. pp. $257-273$

NEILSEN, G.H. \& STEVENSON, D.S., 1983. Leaching of soil calcium, magnesium, and potassium in irrigated orchard lysimeters. Soil Sci. Soc. Am. J. 47, $692-696$.

RAATH, P.J. \& SAAYMAN, D., 1995. Nitrogen mineralisation in vineyard soils of the Western Cape as affected by soil management practices. S. Afr. J. Enol. Vitic. 16, 7 - 13

RAN, Y., HABIB, R., BAR-YOSEF, B. \& EREZ, A., 1994. Root volume effects on nitrogen uptake and partitioning in peach trees. Agron. J. 86, 530 534.

SOIL CLASSIFICATION WORK GROUP, 1991. Soil classification - A taxonomic system for South Africa. Memoirs on natural agricultural resources of Sputh Africa No. 15, Department of Agricultural Development, Pretoria, South Africa. 262 pp. 
STEVENSON, D.S \& NEILSEN, G.H., 1990. Nitrogen additions and losses to drainage in orchard-type irrigated lysimeters. Can. J. Soil. Sci. 70, 11 - 19.

VAN HUYSSTEEN, L., 1989. Soil management for an optimal soil structure for grapevine roots. Proc. 11th Conf. on Tillage and Traffic in Crop Production. Int. Soil Tillage Res. Org., Edinburgh, Scotland, 11 -15 July 1988 pp. 177 - 182.

WALTER, B. \& RESCH, H.N. 1981. Lysimeterversuche der LLVA-Trier. VDLUFA-KONGRESS, Trier, 14 - 19 September 1981, pp. 26 - 38.
WOOD, C.W. \& PETTRY, D.E., 1989. Initial pedogenic progression in a drastically disturbed prime farmland soil. Soil Sci. 147, 196 - 207.

WHITE, R.E., 1988. Leaching. In: WILSON, J.R. (ed.). Advances in nitrogen cycling in Agricultural Ecosystems. CAB International, Wallinford, U.K. pp. $193-211$.

ZEEMAN, A.S., 1981. Oplei. In: BURGER, J. \& DEIST , J. (eds.). Wingerbou in Suid-Afrika. Nietvoorbij, Stellenbosch, South Africa pp. 185 - 201. 